\title{
A CASE STUDY: AN ANALYSIS OF BILINGUAL SYLLABUS DESIGN IN YAMUDA BILINGUAL BOARDING SCHOOL IN TAKENGON
}

\author{
Barep Sarinauli ${ }^{1}$, Isnawi Gayo ${ }^{2}$ \\ STKIP Muhammadiyah Aceh Tengah, naulitkn@gmail.com \\ STKIP Muhammadiyah Aceh Tengah, isnawig5@gmail.com
}

\begin{abstract}
ABSTRAK
Silabus, sebagai bentuk sederhana dari kurikulum dan juga sebagai petunjuk praktis bagi guru saat mengajar, memiliki peran penting dalam proses belajar mengajar. Desain silabus bagi anak-anak yang dibuat oleh guru bahasa Inggris menentukan kesuksesan anak-anak dalam menguasai bahasa asing terutama dalam mengahadapi era globalisasi yakni ketatnya persaingan lapangan kerja di masa yang akan datang. Oleh karena itu, penelitian mengenai analisis silabus perlu dilakukan.Tujuan penelitian ini adalah menganalisa bilingual silabus yang dibuat oleh guru bahasa Inggris kelas dua SD Yamuda Bilingual Boarding School Takengon. berdasarkan konsep silabus yang ideal yang dikembangkan oleh seorang pakar pendidikan bernama Michael P. Breen pada tahun 2001.Kemudian, penelitian ini juga bertujuan untuk mendapatkan persepsi sang guru terhadap pengembangan silabus disamping mengurai kelemahan dan kelebihan silabus yang dibuat oleh guru bahasa Inggris di kelas 2 SD Yamuda Billingual Boarding School. Penelitian ini merupakan penelitian studi kasus kualitatif yang menggunakan sebuah data primer yaitu dokumen berupa silabus dan data sekunder berupa wawancara dengan menggunakan pertanyaan open-question. Dari keenam aspek yang dianalisa, guru bahasa Inggris kelas 2 SD Yamuda sebagai pembuat silabus tidak memasukkan nilai-nilai budaya lokal Aceh sebagai daerah dimana anak-anak tumbuh dan berkembang. Oleh karena itu, hal ini menjadi kelemahan utama dari hasil penelitian ini. Hasil penelitian juga menunjukkan adanya kelemahan dan kelebihan dari silabus yang didisain oleh guru tersebut. Hasil interview menunjukkan bahwa persepsi guru tentang silabus yang dibuat secara kolektif adalah positif dimana silabus tersebut menfasiliasi siswa mereka untuk menguasain bahasa Inggris untuk menghadapi globalisasi.
\end{abstract}

Kata Kunci: Syllabus, Analysis, Bilingual.

\begin{abstract}
This paper analyzed syllabus designed by second grade teacher of elementary level in Yamuda Bilingual Boarding School Takengon. The data employed were a document which was the syllabus and interview result of the English teacher and principal. This is a qualitative case study which analyzed the data by using coding system. The result shows that the English teacher as the designer of the syllabus perceived her collective-planned syllabus positively because it had met the need of her pupils to master the target language and face globalization. Individually, she has a shallow understanding in constructing an ideal syllabus. She might understand the format but not the crucial aspect of syllabus design. Out of six aspects to be reviewed, there are only five aspects fulfilled by her in the syllabus. Yet she did not insert the local content to the syllabus
\end{abstract}


design. Moreover, the syllabus designer neither gave her students a balance diet of language skills nor language aspects. She missed to describe the method used in teaching and learning process and employed a small number of games. On the other hands, this syllabus is a themebased syllabus design which do favor for young language learners to pick up foreign language; the teacher had a good time table of assessment in order to see her students' progress during and after the course. Finally, she also mentioned the teaching objectives which directed her to expand her teaching material.

Key words: Syllabus, Analysis, Bilingual.

\section{Introduction}

\subsection{Background of the Study}

Bilingual education system has been implemented in Indonesia since 2003 in the aims to promote language learners English proficiency. Moreover bilingualism is believed to prepare foreign language learners like in Indonesia to compete in globalization especially in job market competition within national or international community (Cioran, n.d in Tochon, 2009). However, this system has been banned because it contradicted to Indonesian constitution 1945 and Indonesian Law number 20 (2003) (Riana, 2014). Riana's articles in Kompas Edukasi newspaper (2014) also stated that bilingualism is forbidden because it gives unfruitful result for Indonesia final examination (UN) in term of giving too much pressure that the teacher and students have to learn other school subjects in English. She continued that discrimination happened among poor and rich students as well as between faster and lower learners. In term of language, Safitri (2013) in BBC Berita Indonesia wrote that bilingualism had demolished language identity of Indonesia students. However, this paper does not focus on the conflict raised within this system; this paper would like to see if the syllabus design really works to help foreign language students enhance their target language in order to elevate themselves in global community.

Generally, a syllabus design should contain the content or knowledge, the aims and the method of teaching (Graves, 2008; Bourke, 2006; Breen \& Candlin, 2001 and Breen, 2001). However, Michael P. Breen (2001) has layout a detail syllabus definition by composing six important aspects that should be covered in a syllabus design. The knowledge, continuity and direction, course record, formative test, summative test and content. The author analyzed a second term syllabus of second grade of elementary level syllabus by using Breen concept in order to see in what way the bilingual syllabus promotes pupils' competence. This paper analysis also tries to explore the teacher's perception in designing a syllabus by conducting an interview. 


\subsection{Research Questions}

Based on the above background of the study, the research questions would be formulated as the following:

1. Does the second grade of elementary level teacher construct the syllabus based on Michael P. Breen concept?

2. How does the teacher perceive the syllabus?

3. What are the strengths and weaknesses of the syllabus designed by the second grade of elementary level in Yamuda Bilingual Boarding School in Takengon?

\subsection{Objective of Study}

This study aimed to figure out how the teacher perceived the syllabus and whether the syllabus construction was in line with the syllabus concept offered by Breen (2001). Furthermore, this analysis study tried to find the strengths and weaknesses from the syllabus.

\section{Literature Review}

\subsection{Curriculum and Syllabus Definition}

Syllabus Framework and Organization

The role of Syllabus in Language Teaching

Previous research study on Syllabus

\subsection{Elementary School Children}

Teaching English to Elementary School Children
Teaching Skills teaching language aspect

Evaluation

\subsection{Billingualism}

The issue of international language has become one of the agenda in educational policy maker. Due to the increasing multicultural societies, global and regional network and the globalized economy, it seems that English is a bullet to explore the knowledge as well as to facilitate people in participating in various domain of life.As a result, the function of English is not only as lingua franca but also has an impact educational practice where English become the primary motivation to join world community.

Based on the above point of view, bilingual and multilingual education is nowadays essential to pedagogical practice. Bilingual education aims to maintain and revitalize minority language and also to bring a change to the educational world so that the learners are able to develop themselves and are competence to face the global challenge. A broad definition of bilingual education is that it covers a variety of language educational practice whereas bilingual itself refers to the utilization of two languages as a medium of instruction (Baker, 2011).

\section{Research Method}

\subsection{Research Design}

This is a qualitative case study. In qualitative paradigm the researcher is having 
a direct involvement in collecting the data and he or she seeks for an in depth explanations toward the data. Specifically, descriptive data such as document, interview transcript, videotape, and photograph become the focus of the data (Bodgan and Biklen, 1992).

As cited in Bodgan and Biklen (1992), Merriam (1992) points out that case study refers to a detail examination of one setting, one single subject, one particular event or one single depository document. Data is analyzed inductively where the things are open at the beginning and narrower at the end.

This study was conducted to investigate the relevance of syllabus designed by second grade of elementary teacher in Fatih Bilingual School to the theory of syllabus offered by Michael P. Breen (2001). The instrument utilized were the syllabus document of second term of the second grade of elementary level as the primary one and an interview.

\subsection{Research Subject and Object}

The subject of this research was the syllabus and the object was the content of the syllabus. The content was analyzed based on Breen's concept. The next participant was the teacher who designed the curriculum and she was interviewed.

\subsection{Method of Data Collection}

There are two instruments employed in this study. First, the document analysis and second the interview toward the teacher and principle.

\subsubsection{Document Analysis}

The English syllabus from second term of second grade students were analyzed based on Breen's concept (2001). Unlike other experts who worked in education or applied linguistics field, Breen summarized detailed and concise information of an ideal syllabus. Because of this reason, Breen' concept was chosen to be the patron of this research study. Breen mentioned six aspects which should be included in a syllabus; knowledge, continuity and direction, course record, formative test, summative test, and content. The researcher tried to figure out those aspects in the syllabus; whether or not the syllabus was well-constructed.

\subsubsection{Interview}

An interview was given to the teacher who constructed the syllabus. The objective was to know how she perceived the syllabus and whether the syllabus relevance to the six aspects offered by Breen (2001). Moreover, in order to have educational information of the teacher, an interview was also conducted to the principal of the school.

\subsection{Data Collection}

The data was collected by analyzing the syllabus. For example, the first aspect is knowledge which involves language skills (listening, speaking, reading and writing) and language aspects (vocabulary and grammar). The researcher analyzed the data carefully and counted how many meeting of 
listening, speaking, reading and writing skills given in a week, then the number of occurrences of each skill accumulated within a week, a month, and finally within a semester. This technique was also applied in language aspects. In analyzing the evaluation, the researcher checked whether the evaluation is formative or summative test by considering the time given for the pupils. The objectives of study were clearly described in the syllabus. Last, the duration of teaching divided and sequenced orderly from month, weeks, and hours that described 'continuity and direction' as well as 'course record'.

Additionally, recording the statement of the teacher and principle separately related to the syllabus trough an interview became the secondary data of this study. The researcher gave 9 open-questions for the teacher and 4 for the principle. The interview result was recorder and transcript in order to support the primary data.

\subsection{Data Analysis}

To analyze the document, content analysis method was used. According to Bebbie (2010), content analysis is a social method appropriate for studying human communication and behavior. He further explained, in content analysis method, the common unit to be analyzed included words, paragraphs, books, documents, and so forth. To be specific, Bryman (2010) described that in analyzing qualitative data, coding system is a key process used to categorize the data based on its similar principle.

The syllabus and the interview result were both analyzed based on the coding system. The aspects in the syllabus were identified one by one based on Breen's syllabus concept. For example, Breen's first aspect on an ideal syllabus is a clear framework of knowledge and capabilities selected to reach the objective, they researcher identified this element in the syllabus. The similar step was done to the next elements. In addition, interview is conducted to get the secondary data; the result were recorded and transcript. They researcher try to highlighted the information that relevance to the research question which was the perception of the teacher toward syllabus.

\section{The Result of Study and Discussion}

In order to answer the first question, the researcher was analyzing the syllabus and the result of the study shown in the table below:

Table 1. Elements of an ideal syllabus based on Breen (2001)

\begin{tabular}{|c|c|c|c|c|}
\hline $\begin{array}{l}\mathrm{N} \\
\mathrm{o} .\end{array}$ & $\begin{array}{l}\text { Aspect of } \\
\text { Review }\end{array}$ & $\begin{array}{l}\text { Descri } \\
\text { ption }\end{array}$ & $\begin{array}{l}\text { Yes or } \\
\text { No } \\
\text { Statemen } \\
\text { t (only } \\
\text { tick one) }\end{array}$ & $\begin{array}{l}\mathrm{Re} \\
\mathrm{mar} \\
\mathrm{k}\end{array}$ \\
\hline 1 & Knowledge & $\begin{array}{l}\text { A } \\
\text { clear } \\
\text { frame } \\
\text { work } \\
\text { of } \\
\text { knowl } \\
\text { edge } \\
\text { and } \\
\text { capabi } \\
\text { lities }\end{array}$ & $\begin{array}{l}\text { Yes }(\sqrt{ }) \\
\text { No }(\quad)\end{array}$ & \\
\hline
\end{tabular}




\begin{tabular}{|c|c|c|c|}
\hline & & $\begin{array}{l}\text { selecte } \\
\mathrm{d} \text { to be } \\
\text { approp } \\
\text { riate to } \\
\text { overall } \\
\text { aims }\end{array}$ & \\
\hline 2 & $\begin{array}{l}\text { Continuity } \\
\text { and } \\
\text { Direction }\end{array}$ & $\begin{array}{l}\text { Contin } \\
\text { uity } \\
\text { and a } \\
\text { sense } \\
\text { of } \\
\text { directi } \\
\text { on in } \\
\text { classro } \\
\text { om } \\
\text { work } \\
\text { for } \\
\text { teache } \\
r \text { and } \\
\text { studen } \\
\text { ts }\end{array}$ & $\begin{array}{l}\text { Yes }(\sqrt{ }) \\
\text { No }(\quad)\end{array}$ \\
\hline 3 & $\begin{array}{l}\text { Course } \\
\text { record }\end{array}$ & $\begin{array}{l}\text { A } \\
\text { record } \\
\text { for } \\
\text { other } \\
\text { teache } \\
\text { rs of } \\
\text { what } \\
\text { has } \\
\text { been } \\
\text { covere } \\
\text { d in } \\
\text { the } \\
\text { course }\end{array}$ & $\begin{array}{l}\text { Yes }(\sqrt{ }) \\
\text { No }(\quad)\end{array}$ \\
\hline 4 & $\begin{array}{l}\text { Formative } \\
\text { test }\end{array}$ & $\begin{array}{l}\text { A } \\
\text { basis } \\
\text { for } \\
\text { evalua } \\
\text { ting } \\
\text { studen }\end{array}$ & $\begin{array}{l}\text { Yes }(\sqrt{ }) \\
\text { No }(\quad)\end{array}$ \\
\hline
\end{tabular}

\begin{tabular}{|c|c|c|c|}
\hline & & $\begin{array}{l}\text { ts' } \\
\text { progre } \\
\text { ss }\end{array}$ & \\
\hline 5 & $\begin{array}{l}\text { Summative } \\
\text { test }\end{array}$ & $\begin{array}{l}\text { A } \\
\text { basis } \\
\text { for } \\
\text { evalua } \\
\text { ting } \\
\text { the } \\
\text { approp } \\
\text { riatene } \\
\text { ss of } \\
\text { the } \\
\text { course } \\
\text { in } \\
\text { relatio } \\
\text { n to } \\
\text { overall } \\
\text { aims } \\
\text { and } \\
\text { studen } \\
\text { ts } \\
\text { needs } \\
\text { identif } \\
\text { ied } \\
\text { both } \\
\text { before } \\
\text { and } \\
\text { during } \\
\text { the } \\
\text { course }\end{array}$ & $\begin{array}{l}\text { Yes }(\sqrt{ }) \\
\text { No }(\quad)\end{array}$ \\
\hline 6 & Content & $\begin{array}{l}\text { Conte } \\
\text { nt } \\
\text { approp } \\
\text { riate to } \\
\text { the } \\
\text { broade } \\
\text { r } \\
\text { langua } \\
\text { ge }\end{array}$ & $\begin{array}{l}\text { Yes }() \\
\text { No }(\sqrt{ })\end{array}$ \\
\hline
\end{tabular}




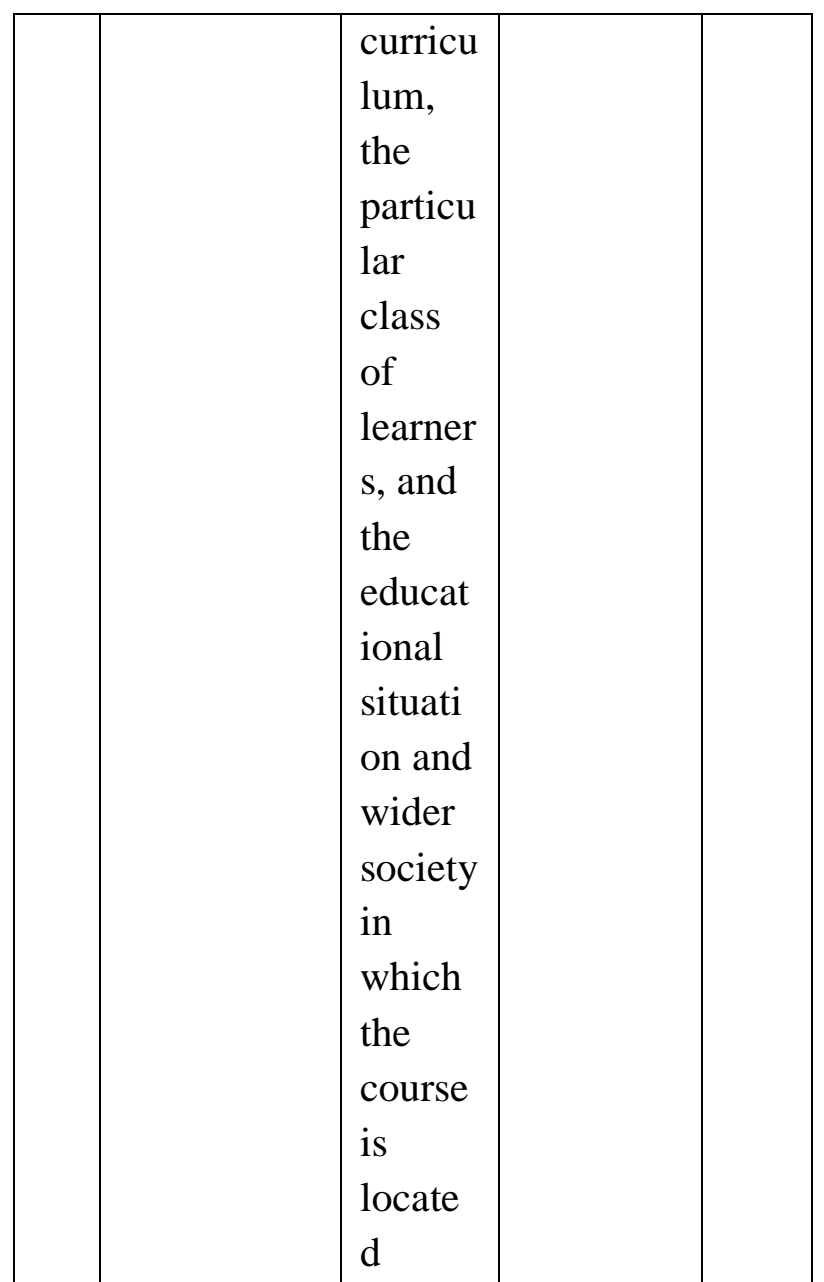

Recalling Breen's concept of syllabus (2001), the component of the syllabus design has fit to the concept or it matched to most of the elements except the last aspect.

Knowledge refers to language skills and aspects taught for the pupils during the semester. They are taught under the certain theme of basic competence. Besides language skills and aspects, the syllabus also included pronunciation covered in speaking skill, capitalization and punctuation covered in writing skill and grammar. The teacher developed the syllabus based on the Standard Competence and Basic
Competence required for elementary students; they are clearly shown in the syllabus.

Continuity and direction are clearly shown in meeting times within a semester. It started in the second week of January and ended up in the final week of May. Within a week, there are 9 hours for English which was divided into two meetings. In a meeting, they spent $2 \times 35$ minutes. For instance, in pronunciation, students learned to listen the beginning vowel "a" and "e" and followed by "i", "o" and " $u$ " in the later meeting. Thus, students were not confused because they were directed by the teacher.

Course record was signaled by two indicators which were the topics and the aims of the lesson. Both of them gave a course record both for the teacher herself and for the other teacher. They helped teacher to prepare and continue the next lesson; they outlined what had been covered and what had not.

Formative test was given periodically by the teacher during the semester. Unit review and midterm test were given to the pupils in order to know their progress per unit and per half semester.

Summative test was also given at the end of the semester. This final test aims to see whether pupils' achievement that described in the standard competence and basic competence.

Content was the aspect that missed from the syllabus. The teacher did not cover the local 
content where the course in taking place. Society value in important in constructing syllabus because it explained the social background of the students.

Pertaining to the second research question, interview result shown that the teacher's perception on the syllabus was positive because it had met their expectation on helping the children to master the target language. Foreign language teaching in faith could benefit children to face the globalization especially in facing the job market. The third research question answered based on the analysis of the syllabus regarding to the theory of language teaching toward elementary school children raised in review of literature and it is discussed as follow.

\section{Conclusion}

Referring to the result of the study, conclusion might be drawn as follow. First of all, this study which attempt to analyze bilingual syllabus document from second grade elementary school of Yamuda Bilingual Boarding School in Takengon. based on the concept of an ideal syllabus offered by Michael P. Breen (2001) brings satisfied outcomes. Out of six aspects to be reviewed from bilingual syllabus that designed by the elementary teacher, there are five which consistence to the concept and one aspect is not. The knowledge, continuity and direction, course record, formative and summative test are recorded in the analyzed syllabus designed by the elementary of second grade of Yamuda
Bilingual Boarding School, yet she failed to bring cultural value into the syllabus.

Interview conducted to the English teacher who designed the syllabus in order to obtain her perception of the syllabus. The syllabus was well-constructed and met their criteria in order to teach their pupil in mastering the foreign language. She added 'It is not an individual syllabus design but it belonged to many English teachers from different provinces within a similar foundation'. It can be inferred that her perception on the syllabus was positive because it is constructed by many English teacher and it has met the children needs and interests. Moreover, the interview result shown that the English teacher seemed to have a shallow understanding of syllabus content, but she had an understanding on the pattern of syllabus because the school foundation gives the teacher to consult and share about their difficulties in designing the lesson documents including syllabus periodically. Surprisingly, the elementary English teacher of second grade of Yamuda Bilingual Boarding School in Banda Aceh admitted that she has no difficulties in designing the syllabus.

The research finding shows that they are some strengths and weaknesses of the syllabus. The most positive point form the syllabus which can trigger students' mastering of their foreign language is the application of theme-based teaching and learning. Thematic teaching and learning has been used in UK and also in Germany. Both of the strong countries have a remarkable outcome to the English program especially in teaching ESL and EFL students. The writer believes that theme- based teaching 
and learning also gives opportunity to EFL students in Indonesia especially in Aceh to promote their English. Third, the evaluation or assessment conducted for young language learners of Yamuda Bilingual Boarding School involves formative and summative test. These two kind of assessments measure pupils' target language proficiency during and at the end of the course in the form of unit test, review, midterm test and final test. It shows that the teachers as the designer of the syllabus concerns about her students' progress during and after the course; this assessment helps her in finding out the strength and weakness of every pupils thus she can make further decision for her teaching.

On the other hands, this syllabus has several weaknesses as well. The top problem from the syllabus design is this syllabus developed without the environment aspect which is significant to a particular syllabus design (Breen and Candlin, 2001; Breen, 2001). The English teacher ignored the social values where the course is taking place. Imbalance portion of language skills as well as language aspects taught to young children has put this syllabus to be absurd. Although, a speculation of skills and grammar teaching laid behind the theories, the teacher, school and foundation should give the best way to teach their young EFL learners. A good syllabus design contains the methodology, yet this syllabus did not mention it straightforwardly or describe it implicitly so this analyzed syllabus could not define as a good syllabus design. There are many ways of techniques for teaching young learners; games are one form many which is best suit to children learning style
(Paul, 2003). Nevertheless, this syllabus had a very limited number of games; during the term, there only two meetings of games. This phenomenon could be caused by the idea that too many games are not effective for some students' learning style.

In addition, according to Jack $\mathrm{C}$. Richards (2001) in his article Course Planning and Syllabus Design, the syllabus designed by the English teacher in Yamuda Bilingual Boarding School is process oriented syllabus or analytic syllabus. This kind of syllabus emphasizes on the exploration and experience attained by the children naturally. The analyzed syllabus is a topic-based syllabus or theme-based syllabus that indicated this syllabus belongs to process-oriented syllabus.

All in all, there are some points of basic conclusion that can be drawn from the study. These points have answered the research questions of this study. In addition, the suggestion of this study offered in the next subheading.

\subsection{Suggestions}

The result of this study shows that there are some significant aspects which should have to be maintained in designing the syllabus. Yet, some improvements still need to be undertaken. Hence, suggestions for further work related to syllabus analysis are offered as follow:

1. Foreign language elementary school teachers, especially in Yamuda Bilingual Boarding School in Takengon should be trained to sharpen their background knowledge of syllabus planning especially the implement Breen's concept of syllabus design. 
Hence, they would not miss some important aspect that should be covered in syllabus design like cultural value (environmental factor), method and technique in teaching for it determines how the practical activities undertaken in an EFL classroom.

2. To ease the burden of EFL language learners especially in second grade of elementary level of Yamuda Bilingual Boarding School, the weaknesses of the syllabus should be improved by teaching language skills and language aspects in a balance portion since they work together; they cannot be taught in isolation. In a syllabus design, oracy and literate skill would support EFL young learners to master their English while grammar and vocabulary building should be planned at the same time and insert to the skill. In order to meet children learning behavior, the teacher as the designer of the syllabus should create a creative and effective games for their young students. While using games, English teacher should drive the class to focus on the learning. On the other hand, the strengths of this syllabus should always be maintained.

3. It is suggested to employ topic-based syllabus or task-based syllabus. In designing the program for young learners because task-based syllabus designed to facilitate second language learning due to the process of comprehensible input and modified output is carried out within the task (Richards, 2001). Additionally, Gass (2003) cited in Block (2003) refers to task based syllabus because Second
Language Acquisition (SLA) development in every child is influenced by 'task'. Bourke (2006) points out that topic based syllabus gives opportunity for children in acquiring the language for the children learn by doing thus syllabus designer should be able to put topic equal to task.

4. Hilado reports that based on his survey in Illinois preschool program (2011), parent involvement is crucial in supporting early childhood program including the syllabus design. In structuring the syllabus, therefore, the parents of grade two in particular and other grades of elementary level in Yamuda Bilingual Boarding School Takengon should be involved by attending parent-teacher conference. Parents should also keep their interaction with the teacher and schools' staff in order to be actively engaged in supporting their child in school.

5.

\section{ACKNOWLEDGEMENTS}

In the name of Allah, the Most Beneficent, the Most Merciful, praise be to Allah SWT. Firstly, I would like to thank Allah SWT who has given me a great apportunity to finish my research. moreover, blessing and peace be upon the Prophet Muhammad SAW who has brought human beings from the darkness into the brightness.

Secondly, I wish to express my sincere love and deepest gratitude to my beloved parents, Suwoto and Kasmirah, who always give me an endless love and abundant understanding. And also I would be keen on conveying my great thankfulness 
to my lovely husband Syaiful Azas, ST who shares happiness and sorrow moments during the time of working this thesis. He and our two doughters, Cindy, Queensha and Alkha are persons who really inspired me and motivated me to work hard to achieve my goal.

Furthermore, I would like to express my gratitude to Head of Department Yamuda School, Dr. Abdiansyah Linge, MA. For for his suggestion, support and direction. I truely realise that without their In addition, my deepest appreciation goes to the Headmaster and English teacher of SD Yamuda Takengon who has provided facilities and other supports to complete my research data.

\section{References}

Adamson, B \& Davidson, C. (2003). Innovation in English language education in Hong Kong primary school: one step forward, two steps sideways? Prospect 18(1), 27-41, retrieved 19 May 2010, A+ Education database.

Baker, C. (2011). Foundations of bilingual education and bilingualism $\left(5^{\text {th }}\right.$ edition). USA: McNaughton \& Gunn LTD.

Bebbie, E. (2010). The practice of social research. (12 ${ }^{\text {th }}$ edition). USA: Wadsworth.

Block, D. (2003). The social turn in second language acquisition. Washington, D.C: Georgetown University Press.

Bogdan, R.C \& Biklen, S.K. (1992). Qualitative research for education: An introduction to theory and methods. ( $2^{\text {nd }}$ edition). USA: Allyn and Bacon.

Bourke, J.M. (2006). Designing topic-based syllabus for young learners. ELT Journal, 60(3), 279-286. Oxford University Press.

Breen, M.P. (2001). Syllabus design. R. Carter \& D Nunan, The Cambridge guide to teaching English to speakers of other language. (pp. 151-159).

Breen, M.P \& Candlin, N. (2001).The essential of a communicative curriculum in language teaching. In DR. Hall \& A Hewings (Eds.), Innovation in English language teaching. (pp. 9-25). London: Routledge.

Brewster, J. (1991). Listening and the young learner. In Brumfit. C, Moon. J \& Tongue. R (Eds.), Teaching English to children: from practice to principle (pp.V-VIII). Collins ELT. London.

Brumfit, C. (1991). Introduction: teaching English to children. In Brumfit. C, Moon. J \& Tongue. R (Eds.), Teaching English to children: from practice to principle (pp.V-VIII). Collins ELT. London.

Bryman, A. Content analysis: Coding I. retrieved 4 December 2013 form http://www.youtube.com/watch?v=7 $\underline{\mathrm{X} 7 \mathrm{VuQxPfpk}}$

Cameron, L. (2001). Teaching language to young learners. Cambridge University Press: Cambridge. 
Desmita. (2009). Psikologi perkembangan.

(5th Ed.). Bandung: PT Remaja

Rosdakarya Bandung.

Ellis, R. (2012). The structural syllabus and second language acquisition. TESOL Quarterly 27(1), 91-113.

Fatih Bilingual Boarding School. (n.d). History: Fatih bilingual boarding school. Retrieved $14^{\text {th }}$ February 2014 , from http://sekolahfatih.wordpress.com/ab out/history/

Graves, K. (2008). The language curriculum: a social contextual perspective. Language Teaching, 41(2), 147-181, retrieved 26 May 2010, Cambridge Journals database.

Harnish, R.J. and Bridges, K.R. (2011). Effect of syllabus tone: students' perceptions of instructor and course. Social Psychology Education (14), 319-330.

Harmer, J. (2007). The practice of English language teaching, $4^{\text {th }}$ edn. Pearson Education: Harlow.

Hilado, A., Kallemeyn, L., Leow, C., Lundy, M. \& Israel, M. (2011). Supporting child welfare and parent involvement in preschool program. Early Childhood Education Journal. 39, 343-353.

Hurst, N.R (n.d). Notional syllabus: Twenty years one, 24(199), 489-504, retrieved on 29 May 2013. (ler.letras.up.pt/uploads/ficheiros/27 71.pdf)

Jones, G.M. (2001).Bilingual education and syllabus design: Towards a workable blueprint. In DR. Hall \& A. Hewings (Eds.), Innovation in English Language Teaching. (pp. 99-108). London: Routledge.

Kemdikbud. (2013). Surat edaran kemdikbud tentang kebijakan transisi RSBI. Retrieved $21^{\text {st }}$ February 2014, form http://www.antaranews.com/berita/3 56000/mendikbud--sekolah-eks-rsbiberstatus-sekolah-reguler.pdf.

Kementrian Pendidikan Nasional. (n.d). Kebijakan Rintisan Sekolah Berstandar International. Retrieved $21^{\text {st }}$ February 2014, from http://www.google.com/url?sa=t\&rct $=\mathrm{j} \& \mathrm{q}=\& e s r c=s \&$ source $=$ web $\& \mathrm{~cd}=1$ \&ved=0CCUQFjAA\&url=http\%3A $\% 2 \mathrm{~F} \% 2 \mathrm{Fdikdas} . k e m d i k n a s . g o . i d \% 2$ Fdocs\%2. pdf.

Koryati. (2011). The role of syllabus: the documentatios requirement of ISO 9001: 2008. Jurnal Holistik (3)5, 1222.

McKay, P. (2006). Assessing young language learners. (Eds.), Alderson, J. C and Bachman, L. F. Cambridge: Cambridge University Press.

Moran, P.R. (2001). Teaching culture: perspective in practice. (Eds.), Freeman, D. Canada: Heinle \& Heinle Thompson Learning. Mulyasari, E. (2010). Bilingualism at preschool supports further education (A case study of a preschool in Bandung Indonesia). Kuala Lumpur: APAC. 
Pantaleoni, L. (1991). L2 syllabusing at primary level: The Italian perspective. In Brumfit.C. J Moon \& R. Tongue, Teaching English to Children: Frpm Practice to Principle. (pp. 302-308). London: Harper Collins Publisher.

Paul, D. (2003). Teaching English to children in Asia. Hong Kong: Pearson Longman Asia ELT.

Rabbini, R. (2002). An introduction to a syllabus design and evaluation. The internet TESL journal. VIII(5), 1-6.

Riana, A. (2014). MK: RSBI tidak sesuai konstitusi. Retrieved, February $22^{\text {nd }}$ 2014 , fromhttp://edukasi.kompas.com/read/ 2013/01/08/15514869/MK.RSBI.Tid ak.Sesuai.Konstitusi.

Richards, J.C. (2001). Course planning and syllabus design. Curriculum Development in language teaching. (pp.145-197).

Safitri, D. (2013). MK Kabulkan gugatan tolak RSBI. Retrieved, Ferbuary $22^{\text {nd }}$ , 2014, form http://www.bbc.co.uk/indonesia/berit a_indonesia/2013/01/130107_mkrsbi .shtml/

Scott, W.A. \& Ytreberg, L.H.(n.d). Teaching English to children. London New York: Longman.

Shin. J. K. (n.d). Teaching English to young learners. In English Language Center. Baltimore Country: University of Maryland.
Syamsuddin, A.R \& Damaianti, V.S. (2009). Metode Penelitian Pendidikan Bahasa. Bandung: Remaja Rosdakarya.

Tochon, F.V. (2009). The key to global understanding: world languages education- why schools need to adapt. Review of educational research, 79(2), 650-681, retrieved 19 May 2010, Sage Premier database. 